\title{
DIDACTICS OF HIGHER EDUCATION IN THE CONTEXT OF INFORMATION TECHNOLOGY
}

\author{
Tomasz WARZOCHA*, University of Rzeszow, Poland
}

\author{
Received: 21. 7. 2017 / Accepted: 1. 10. 2017 \\ Type of article: Review article \\ DOI: $10.5507 /$ jtie. 2017.022
}

Abstract: This article contains information on the use of information technology in the teaching process at the higher education level. Tools that assist the process of acquiring, processing, storing, and transferring information play a very important role in the educational process. The academic teacher, in order to meet the demands of the generation of young students who are fluent in the information technology used in everyday life, should constantly improve their knowledge and skills in lifelong learning. The teacher's practice should be supplemented with new technological tools to support the process of transferring information to students. The ability to use information technology in a classroom activity may be the basis for concluding that an academic teacher has adequate information literacy in this area.

Keywords: didactics, information technology, academic teacher, college.

\section{DYDAKTYKA SZKOLY WYŻSZEJ W KONTEKŚCIE TECHNOLOGII INFORMACYJNYCH}

Abstrakt: Artykut zawiera informacje na temat wykorzystania technologii informacyjnych $w$ procesie nauczania na poziomie szkoty wyższej. Narzędzia wspomagajace proces pozyskiwania, przetwarzania, przechowywania $i$ przekazywania informacji odgrywaja bardzo ważna role $w$ procesie edukacyjnym. nauczyciel akademicki chcac sprostać wymaganiom stawianym przez pokolenia młodych studentów, którzy biegle postuguja się technologiami informacyjnymi stosowanymi $w$ życiu codziennym, powinien stale pogłębiaja swoja wiedzę $i$ umiejętności $w$ procesie ksztatcenia całożyciowego. Warsztat nauczyciela akademickiego powinien być uzupetniany o nowe narzędzia technologiczne, wspierajace proces przekazywania informacji studentom. Umiejętność korzystania $z$ technologii informacyjnych $w$ prowadzonych zajęciach, może być podstawa do stwierdzenia, że nauczyciel akademicki posiada odpowiednie kompetencje informacyjne w tym zakresie.

Słowa kluczowe: dydaktyka, tehnologie informacyjne, nauczyciel akademicki.

\footnotetext{
*Autor pro korespondenci: twarzocha@ur.edu.pl
} 


\section{Introduction}

The development of information technologies, aimed at improving didactic processes, is dependent on the continuous improvement of the ability to use them in the professional work of every teacher. The current generation of students who have grown up in environments where information technology is available at their fingertips requires the academic teacher to use them in their practice. Competence in this area will streamline the educational process in higher education where the teacher and student should work closely together to achieve the intended end result. Access to information technologies sometimes ends at the knowledge that they exist, but they are not used. This may be due to lack of information about them and the possibilities of their use, as well as fear of damaging them on the part of the teacher and, even more, the student. Consequently, both the student and, above all, the educator, in order to be up-to-date with technological advancements that enhance the learning process, should continue to deepen their knowledge, participate in technology workshops, and then reflect on how they can be utilized in professional work. Every university, therefore, is faced with the very difficult task of meeting the demands set by students who are proficient in information technologies.

\section{Higher education didactics}

Didactics comes from the Greek word "didasco" - I teach, "didacticos" - instructive. It is the science dealing with the processes of teaching and learning. This word was first used by J. Jung and K. Helwig in Germany in the seventeenth century to describe didactics as the art of transferring information carried out by a teacher, as a mentor who has the appropriate knowledge resources. At the time it was the only pedagogical science. Because of its interdisciplinary character, there is no clear definition of the word didactics. Undoubtedly, it is a science which includes the relationship between the teacher and the learner. W. Okon defining the notion of didactics, also refers to a learning process in which the following components are distinguished:

a) teachers and their working methods;

b) learners and their needs;

c) the content of education, methods;

d) the environment in which knowledge is transferred (Okoń, 2003).

One of the basic notions of didactics is learning, understood in different ways by researchers dealing with this problem.

According to B. Nawroczyński it is a process connected with active acquisition of messages and efficiency (Nawroczyński, 1961). Cz. Kupisiewicz defines it as a process of active acquisition of knowledge, skills and habits in the process of getting to know reality directly and indirectly (Kupisiewicz, 2009). 
The above definitions show that didactics is a process which involves the teacher, who is responsible for reliable knowledge transfer, and a student, whose task is to acquire such knowledge. It is up to the academic teacher to determine how they will present a given problem and what methods, means and tools will be used for this purpose.

Every process of gaining knowledge - learning - is related to the activity of the learner. The greater the discipline, the better the final result, which is reflected in the credits obtained during and at the end of each semester in universities. Undoubtedly, it is still true that each of the subjects taught requires a different approach, the use of different teaching methods and means. Technical subjects will be easier to explain using the appropriate machines, equipment and information technology in appropriately equipped workshops and laboratories. Humanities subjects are better presented in a verbal way, simply enriched, for example, with a prepared multimedia presentation. Since we take in most information from the senses, a well-prepared presentation can say more than hundreds of incomprehensible words. Similarly, in the case of experiences which in reality are phenomena that can be depicted, we can read about them in a book. Unfortunately, theory itself is insufficient. Lack of practical experience means that sometimes we read or talk about something we have never before been able to see, experience or undergo. Of course, theoretical knowledge is the basis for the performance of practical tasks.

\section{Competence of an academic teacher in the use of information technology}

The academic teacher, as a person responsible for the transfer of knowledge, is obliged to continually deepen their knowledge, based on the latest research, of the information available in a particular field. Students, as persons who have grown up with information technologies, require educators in higher education to use them systematically. This greatly improves the process of exchanging information between an academic teacher and a student. The introduction and use of information technologies in classroom activities requires the teacher to be competent in this area.

Like the word didactics, there is no clearly defined concept of competence. It comes from the Latin word "competentia" - meaning having the knowledge that allows a person to make a judgement, an authoritative statement, on a range of issues that a person can pass judgment on, due to having the relevant knowledge (Furmanek, 1997). M. CzerpaniakWalczak defines it as attributes expressed in the demonstration of the level of ability of appropriate behaviour defined by social standards, the consequences of such behaviours, and the assumption of responsibility (M. Czerpaniak-Walczak, 1999).

From the above definitions, it is apparent that competence is defined as having knowledge in a certain range, allowing you to perform tasks at a certain level, taking full responsibility for the end result. If we relate this to an academic teacher, we can say that they are competent if they have the proper preparation to pursue their profession, based on experience that allows the knowledge of their field to be efficiently and skilfully transferred.

The ability of an academic teacher to acquire, process, transfer and store information is often linked to the use of information technology for this purpose. The possibilities of new tools supporting the educational process are enormous. However, the academic teacher should skilfully introduce and use them in their practice. When acquiring information on the Internet, it is necessary to verify its reliability. The information overload - information noise - that is generally available, means that we are not always 
able to accurately evaluate and verify whether the information is true or whether we should look somewhere else. It is very difficult to process acquired data without the use of information technology. An academic teacher, as a person with social authority, not wanting to be excluded in the information and digital realms should present a given topic using tools that support the didactic process. One of the simplest forms is to develop multimedia presentations using appropriate software, such as MS PowerPoint, Prezi, etc. More technologically advanced teachers provide material on topics discussed in the course as PDFs on their private websites, discussion forums, thematic groups, etc. This allows a simpler way to work with young people who have grown up with information technology and for whom acquiring information from the web is not a major problem. Educators with long career experience are often reluctant to accept such solutions because they have triedand-tested methods that they have become accustomed to. The older the academic teacher, the lower the use of information technology in the teaching process, which results from the greater stress caused by their inability to use them. This is also confirmed by studies conducted by British psychologists (Tucholska, 1999).

Compiled data obtained on the Internet using information technology can be edited in an easy, fast and simple way at any time. There is no need to take heavy books, or notes to present specific issues. From anywhere in the world with access to the Internet, we can download and explore data that we have prepared. One of the available places where we can gather data, including presentations, instructional videos, or other electronic materials, is virtual hard drives. Students seeing an academic teacher skilfully using information technology are more likely to make contact with them and exchange experiences. Having appropriate competence in the use of information technology supporting the teaching process at higher education institutions can protect an academic teacher from digital exclusion. Otherwise, as the development of technology goes forward at a very fast pace, it will be inevitable. An effective teacher is a well-prepared teacher with the help of various types of computer programs (Bułka \& Fiebich 2011).

The report Key data for education and innovation in the use of information and communications technology in schools in Europe outlines strategies for ICT teacher training as well as the basis for the development of IT techniques and tools used in professional work. One of the main goals was to identify proficiency in information technology, internet search skills, social media skills (EURYDICE, 2011).

Higher education institutions are often equipped with state-of-the-art technology, which can be used in the didactic process, and for scientific research, either for selfdevelopment or science. Sometimes it is possible to find that well-equipped laboratories, unfortunately, are only a physical place not used by the teaching staff in the higher education institution. The lack of knowledge and information on the possibility of using information technology in the professional work of academic teachers means that great potential is wasted. The solution may be training as part of the further education of academic staff wishing to use information technology in working with students. Suitably carried out workshops in terms of content, but above all in practical terms, minimize the sense of fear and concerns about damaging the equipment, and perhaps even encourage and open up the academic teacher to exploring ways in which they can use technology in their classes.

Training is needed to the level that is needed to achieve the goal of introducing information technology into schools, creating the necessary pedagogical teams to support teachers in overcoming the difficulties associated with their use in educational processes 
(Urwin, 2007). Training of academic teachers should be a continuous process rather than a one-time initiative. Technology development is proceeding at a very fast pace, so workshops should be based on up-to-date technologies available in academic environments that will allow the creation of centres, learning environments that respond to the culture of collaboration in the use of ICT in the organizational structures of the particular institutions concerned.

\section{Examples of using information technology in higher education}

Information technologies used in higher education in educational processes are often limited to the basic functions they are supposed to fulfil. One of the simplest examples is to use an interactive whiteboard with a projector serving as a place to display a multimedia presentation. A small number of teachers are able to take full advantage of its capabilities, which are very large. Well-prepared tasks for working with an interactive whiteboard allow students to be actively involved in their classes. In addition, connecting with tablets allows them to be used as tools for checking the knowledge acquired during the didactic process. Of course, the preparation of good materials takes more time than traditional methods, but once prepared they can later be used many times. An additional plus of this way of transferring information is that younger students will willingly participate in such classes where information technology is used because they have grown up among them.

Another example of information technology used at universities is electronic copyboards. One of the main differences with interactive whiteboards is that real-time data is saved immediately. Unfortunately, they cannot display interactive content such as movies, audio files, and others.

Another tool that academic teachers have access to is the visualization tool, which is used to transfer knowledge from printed literature. It is sufficient to simply place a given part of a book, object or photo under the camera to view the subject.

A very neat solution, though rarely used and seen in universities, are test systems. After classes, the academic teacher can easily check the students' knowledge. All they have to do is design the appropriate test and enter the names of the participants, for example a group of students from a given course, year or specialisation. In this way verbal knowledge verification would be replaced by electronic means with automatic scoring of the correct answers given for each student.

One system for communicating with other academic centres is videoconferencing sets. These types of solutions are often encountered, and, thanks to the unified system, they are able to connect to other higher education institutions or branches of the same university in another location without the need for additional platforms. This is a technology that is so convenient that with access to the Internet it is not necessary to physically participate in an event organized in a certain place. Properly configured settings for video conferencing systems allow the conducting of scientific conferences at any time from anywhere in the world. Similar solutions are used during medical consultations in surgical operations, where one physician uses a camera to convey the image of an organ undergoing treatment to the screen of another doctor anywhere in the world (MedicalSony).

The examples presented above are only a selection of the information technologies used in didactic processes in higher education institutions. It is the teacher who is responsible for the process of transferring knowledge, and is obliged to choose the ways, 
techniques and methods that they will use in their activities. Only continuous development in gaining experience resulting from the development of tools supporting the educational process may be the basis for the avoidance of digital exclusion, which will be constantly exposed when in contact with young people who are proficient in using these tools.

\section{Conclusion}

Information technology in higher education is a tool to assist in the process of acquiring, processing, transferring and storing information acquired from the Internet. The academic teacher as a mentor, the person standing in the middle of this process, should skilfully use these tools in their practice. Showing the opportunities that come from the use of information technology will make the younger generation of students, raised among such technological solutions, more likely to engage in active participation in classes. A lack of available equipment, or a fear of damaging it, causes technology not to be used and universities therefore to be unable to prepare students to work in the information society based on it. Sometimes higher education is the only place where young people have a chance to become acquainted with the essence of a given technology before entering the labour market. Access to new technologies, the ability to use them practically by students, can make it much easier for them to use them in their future work. For employers, practical skills are often more important than theoretical knowledge, so a higher education institution should equip young students with the skills they need to master the necessary knowledge both in terms of content and practicality. Only in this case will college graduates find a place in the society in which information and communication technologies play an important role. Academic teachers' possession of the appropriate information competencies is the basis for further practical tasks related to their use in practice in the didactic process in higher education institutions. Having the appropriate ICT skills of academic teachers is the basis for further practical tasks related to their use in practice in the teaching process in higher education institutions. It is an academic who wants to meet the challenges faced by young generation of students brought up with information technologies, should complement, enrich their workshop with new technological solutions supporting the process of acquiring, processing and transferring knowledge. Only lifelong skills development, can be the basis of the absence of digital exclusion

\section{Literature}

Bułka B., Fiebich Ł.(2011). Kompetencje nauczycieli w zakresie technologii informacyjnej [w:] J. Migdałek, A. Stolińska: „Technologie informacyjne w warsztacie nauczyciela. Nowe wyzwania edukacyjne", Kraków

Czerpaniak-Walczak M.,(1999). Kompetencja: Stowo kluczowe czy ,wytrych” w edukacji?, Poznań

EURYDICE.(2011). Kluczowe dane o ksztatceniu i innowacjach z zastosowaniem technologii informacyjno-komunikacyjnych $w$ szkołach $w$ Europie, Warszawa Furmanek W.(1997). Kompetencje - próba określenia pojęcia, Edukacja Ogólnotechniczna 7

Kupisiewicz Cz. (2009). Słownik pedagogiczny, Warszawa

Nawroczyński B. (1961). Zasady nauczania, Wrocław

Okoń W., (2003). Wprowadzenie do dydaktyki ogólnej, Warszawa 
Tucholska S. (1999). Stres zawodowy u nauczycieli. Poziom nasilenia i symptomy., Psychologia wychowawcza $\mathrm{nr} 3$

Urwin A. (2007). The professionalism of the higher education teacher: what's ICT got to do with it?., Teaching in Higher Education, Vol.12, No.3,

http://www.pro.sony.eu/pro/lang/pl/eu/article/medical-sony-3d 